\title{
Equipping Social Workers to Address Spirituality in Practice Settings: A Model Curriculum
}

\author{
David R. Hodge
}

Abstract: While there is growing interest in incorporating dients' spiritual beliefs and values into social work practice, several studies haveshown that social workers lack the necessary training to address spiritual issues in a culturally competent manner. This paper addresses this need by providing an annotated spirituality training coursefor use in various settings. Topics or domains covered in thecurriculum includeethics and values, research and theory on spiritual ity, the nation's spiritual demographics, thecultures of major spiritual traditions, value conflicts, spiritual interventions, assessment approaches, and the rights of spiritual believers. A number of potential assignments areoffered, which are designed to promote practitioner self-awareness, respect for spiritual diversity, and an enhanced ability to assess and operationalize spi ritual strengths to ameliorate problems in practice settings.

Keywords: Spi rituality, course curriculum, training, education, religion

\begin{abstract}
- Were is growing realization that for many clients spirituality is fundamental to their existence. Spiritual belief systems often function as an interpretive framework for understanding reality, informing individuals of who they are and how they should live (Maslow, 1968). As Rey (1997) has observed, these spiritually informed worldviews can affect numerous attitudes and practices of significance to social workers. For instance, bereavement, childcare, diet, intergenerational relationships, marriage relations, medical care, military participation, recreation practices, and schooling are all areas in which clients' spirituality can affect beliefs and actions.
\end{abstract}

Evidence is also building that spirituality is a significant personal strength for many clients. Several hundred studies on spirituality and religion have been conducted during the past few decades (Koenig, McCullough \& Larson, 2001). Reviews have consistently found a generally positive association between spirituality and a wide number of salutary characteristics (Ellison \& Levin, 1998; Gartner, 1996; Koenig et al., 2001; Pargament, 1997). For example, various dimensions of spirituality

David R. Hodge, M.C.S., M.S.W. is a Rene Sand doctoral fellow, George Warren Brown School of Social Work, Washington University, St. Louis, MO 63130-4899.

Copyright ${ }^{\circ} 2002$ Advances in Social Work Vol. 3 No. 2 (Fall 2002) 85-103. Indiana University School of Social Work. 
have been associated with empowerment (Calhoun-Brown, 1998; Maton \& Salem, 1995), female leadership (Robinson, 1996), healing (Maton \& Wells, 1995; McRae, Thompson \& Cooper, 1999) and recovery from addiction (Turner, O’Dell \& Weaver, 1999), depression (Propst, 1996), divorce (Nathanson, 1995), homelessness (Lindsey, Kurtz, Jarvis, Williams \& Nackerud, 2000; Montgomery, 1994), serious mental illness (Sullivan, 1997), and sexual assault (Kennedy, Davis \& Talyor, 1998).

Research also indicates that many clients wish to incorporate their spiritual strengths into practice settings (Privette, Quackenbos \& Bundrick, 1994). According to Gallup data reported by Bart (1998), $66 \%$ of the public would prefer to see a professional counselor with spiritual values and beliefs and $81 \%$ wanted to have their own values and beliefs integrated into the counseling process. Approximately $60 \%$ of the public believe that their faith can be marshaled to address most of the problems they encounter (Gallup \& Castelli, 1989). Furthermore, the salience of spirituality frequently becomes more prominent during times of personal hardship (Ferraro \& Kelley-Moore, 2000; Pargament, 1997), times when social workers may be more likely to encounter clients.

As the NASW Code of Ethics (National Association of Social Workers, 1999) standard 1.05 stipulates, it is important for social workers to increase their understanding regarding the unique characteristics of spiritually-based cultures to be able to provide culturally competent services to clients. Several surveys have shown, however, that most social workers have received no training in spirituality during their graduate education (Bullis, 1996; Canda \& Furman, 1999; Derezotes, 1995; Furman \& Chandy, 1994; Furman, Benson, Grimwood \& Franz, unpublished manuscript; Sheridan \& Amato-von Hemert, 1999). For instance, Canda and Furman's (1999) stratified random sample of the National Association of Social Work (NASW) members $(N=2,069)$ found that $73 \%$ received no content on spirituality during their social work education and only $17 \%$ agreed that social workers possessed the knowledge to address spiritual issues. While most social workers recognize the importance of spirituality, the data suggest that many social workers are not adequately equipped to address spirituality in practice settings (Canda \& Furman, 1999).

The lack of education implies that widespread training is required in this area. Accordingly, this paper addresses the need by presenting a spirituality-training curriculum. The aim of the curriculum is to develop an understanding of spiritual diversity and lay a foundation for acquiring the necessary skills and knowledge to utilize spirituality in various practice settings in the areas of assessment, planning, and intervention. Toward this end, the three-fold objective is to develop a deeper understanding of the empirical and theoretical knowledge base, acquire a greater understanding of the various spiritual traditions practitioners are likely to encounter in practice settings, and develop the skills necessary to utilize spirituality in practice settings to ameliorate problems in a manner consistent with the profession's ethical mandates.

The curriculum can beadapted to a number of different settings, including agencybased workshops, short-term seminars, graduatelevel courses, small groups, or even self-study. This is accomplished by adjusting the amount of material addressed in various contexts, such as classroom settings, small groups outside of class, and homework assignments. Since curriculum material consists of a number of articles/ 
book chapters designed to address specific topics, contextual alterations can be made to tailor the material by incorporating additional pertinent readings. While compiling the material is more work than merely assigning textbooks, the reading packet serves as a type of textbook itself and can be continually updated by adding new articles as the knowledge base grows over time (Patterson, Hayworth, Turner Christie \& Raskin, 2000).

As implied above, this paper provides an annotated overview of the curriculum material. There are 10 major domains or topics that might beconsidered in designing a spirituality curriculum: 1) ethics and values, 2) a review of the empirical research on spirituality, 3) theoretical explanations for spiritual strengths, 4) spiritual demographics of the nation, 5) an overview of the nation's major spiritual traditions, 6) value conflicts, 7) spiritually-based interventions, 8) assessment and operationalization of spiritual strengths, 9) rights of spi ritual believers, and 10) assignment suggestions. The material below is presented in a manner that highlights connections between readings and emphasizes pertinent themes that can be amplified upon in discussion or through personal reflection. The major topics are reviewed in the sequence in which they would be presented in a seminar, workshop, or course. Small-scale mini-assignments to enhance learning, which might take the form of class discussion topics or reflective take-home papers, are suggested for most domains. In a section at the end of the paper, suggestions for major assignments that help to integrate the material are provided.

The material presented below is also designed to be consistent with the Foundation Curriculum Content requirements specified in the Educational Policy and Accreditation Standards (EPAS) issued by the Council on Social Work Education (CSWE) (2001: IV). More specifically, the suggested domains and assignments have been created to foster learning in the content areas listed in the EPAS as they intersect spirituality; namely, values and ethics, research, human behavior and the social environment, diversity, populations-at-risk and social and economic justice, social work practice, and to a lesser extent, social welfare policy and services.

\section{ETHICSAND VALUES}

An appropriate place to begin a presentation on spiritual ity is with the profession's code of ethics (National Association of Social Workers, 1999). As the EPAS standards IV and A (Council on Social Work Education, 2001) state, education should provide students with the opportunity to integrate the NASW Code of Ethics into their practice with, and service to, clients. Three areas of particular significance are the standards related to client self-determination, religion, and professional competence. It is important to note that social workers are to respect the spiritual autonomy of clients (1.02). Practitioners must be careful not to impose or otherwise coerce clients into accepting their values. Richards, Rector, and Tjeltveit (1999) provide a concise overview of the intersect between values and spirituality in the clinical setting, along with helpful suggestions for safeguarding clients' rights in the area of autonomy. As supplemental reading to raise awareness concerning value differences, Jafari (1993) offers an Islamic view that helps to illustrate how the values associated with the Enlightenment-based Western counseling project may differ from the values associated with some faith-based perspectives. 
The NASW Code of Ethics (National Association of Social Workers, 1999) lists four standards that explicitly address religion (1.05c, 2.01b, 4.02, and 6.04d), the vehicle through which most, although not all, clients express their spirituality (Gallup \& Lindsay, 1999; Pargament, 1999). Furthermore, since religious believers comprise distinct cultural groups based on the norms of their faith traditions (Fellin, 2000; Talbot, 2000), there are at least two standards that implicitly address religion (1.05a, 1.05b). These standards can be reviewed and their implications regarding how social workers should interact with religious peoples examined.

Social workers are also mandated to offer services only within their area of professional competency (1.04). Practitioners do not function in the role of a pastor or spiritual director/mentor (O'Rourke, 1997). While it is generally appropriate for social workers to attempt to tap into clients' spiritual strengths to assist them in solving their problems, it is essentially outside practitioners' area of competence to address issues related to clients' spiritual well-being. Put simply, social workers should focus on helping clients overcomethe obstacles they face rather than offering advice on clients' spiritual state, beliefs, practices, or behaviors. Social workers who envision themselves as working with spiritual issues on a regular basis should consider forming collaborations with local clergy drawn from the most prominent local faith traditions (Weaver, Koenig \& Larson, 1997).

To help assimilate this material, course participants might consider what type of practitioner responses would engender a practice atmosphere that promotes creating a safe place in which spirituality can be explored in a non-judgmental manner. At some point in the curriculum, ethical dilemmas could be analyzed in light of the ethical standards discussed above (Council on Social Work Education, 2001: IV, A). For instance, given that Islam affirms sexuality within the context of heterosexual marriage (Halstead \& Lewicka, 1998; Islamic Society of North America, 1999), the challenges that a gay therapist might face with a Muslim client wrestling with her sexual orientation might be explored.

\section{REVEWOF THE EMPIRICAL RESEARCH}

As implied above, research on spirituality is increasing at a dramatic rate, with hundreds of studies on the topic now in existence (Koenig et al., 2001). The results of these studies have been remarkably consistent across populations regardless of age, ethnicity, gender, national origin, race, religious affiliation, and study design (Ellison \& Levin, 1998; McFadden \& Levin, 1996). Reviews consistently report a generally positive association between devout faith and a wide number of salutary characteristics (Ellison \& Levin, 1998; Gartner, 1996; Koenig et al., 2001; Pargament, 1997).

The following articles provide a window on this growing body of empirical knowledge. After reading these five articles, students may be surprised at the breadth of available research. Interested individuals should be informed that research exists on most populations and issues of interest to social workers.

Green, Fullilove, and Fullilove (1998) offer a good entry point into the research with their qualitative study that describes stories of spiritual awakenings among participants of 12-step programs. The narrative format affords students theoppor- 
tunity to encounter an experiential, phenomenological element that often gets lost in research. Worthington, Kurusu, McCullough, and Sandage (1996) present a thorough 10-year review of research that relates to practice concerns, such as studies on the relationship between spirituality and mental health, the role of values in therapy, and effective interventions. In Maton and Wells' (1995) review, the potential of religion to foster well-being through the pathways of prevention, healing, and empowerment is examined.

This content area also includes two studies that highlight the salience of spirituality with specific populations of interest to social workers. Donahue and Benson's (1995) study illustrates the significance of religion as a protective factor with adolescents, with religion often exhibiting a stronger influence than gender, single parent status, and other variables widely thought to be significant predictors of attitudes and behaviors. Kennedy, Davis, and Talyor's (1998) study documents the role of spirituality in facilitating recovery from sexual assault among a sample comprised largely of inner city minority women.

Since this section is oriented towards empiricism, it may be difficult to provide an assignment to help foster learning in this topic area. Accordingly, this may be an appropriate time to integrate into the course one of the major assignments discussed later in this paper. Alternatively, when the course is being taught in a CSWE-accredited educational institution and/or students have an understanding of research methodology, students might critique some of the existing research, explore, and summarize the existing research in a given area (e.g., the relationship between spirituality and depression), relying on good reviews such as Koenig, McCullough, and Larson's (Koenig et al., 2001), or conduct a literature search to explore the intersection between spirituality and a given population, such as African-Americans or the elderly.

\section{THEORETICAL EXPLANATIONS}

As the CSWE's educational standards (Council on Social Work Education, 2001: IV, D) imply, it is important for students to be exposed to empirically-based theories that explain the relationships between humans and their environments with an emphasis on the relationships that maintain and promote health and well-being. As interest in researching the effects of spirituality has grown, a number of theories have been proposed to explain the underlying mechanisms. While the preceding domain helps students understand the nature of spiritual assets, theory can assist course participants in their comprehension of the pathways involved. In other words, theory provides an explanation for how spirituality fosters positive outcomes.

Ellison and Levin (1998) provide a smooth transition from overviewing the research to discussing theoretical explanations for the association between religion and health. Seven possible explanatory mechanisms are reviewed, which may account for salutary outcomes, including the provision of social resources, promotion of positive self-perceptions, and provision of specific coping resources. Jacobs (1992) explores the underlying mechanisms between mental health and ritual, a key spiritual practice inherent in essentially all faith traditions. Finally, borrowing from attachment theory, Kirkpatrick (1995) suggests that God functions as 
an attachment figure. Since attachment is theorized to be a malleable construct that can change over time, the negative effects of insecure childhood attachment can be compensated for by developing a secure attachment with a divine other.

For enhanced learning, students can reflect upon the various theoretical mechanisms as they intersect their own lives, or the lives of other significant individuals they know. Which theoretical explanations best explain the spiritual strengths they observe in their own lives? The lives of others? Do other theoretical pathways exist that provide a better theoretical explanation for the operation of spiritual strengths? If students had to construct their own theoretical model to describethe relationship between spirituality and well-being, what might it look like?

\section{DEMOGRAPHICS AND OVERVEW OF MAYOR SPIRITUAL TRADITIONS INTHE NATION}

While diversity is a fundamental tenet of social work education (Council on Social Work Education, 2001: IV, B), in practice, individuals tend to form social networks based upon shared norms and values (Scheepers \& Van Der Slik, 1998). Because people tend to enter into relationships, watch media, and read news reports that validate their own understanding of reality, individuals may not have an accurate understanding of the nation's spiritual demographics. Alternatively, individuals may only be dimly aware of other faith traditions and their own unique worldviews.

To counter misperceptions, it is important to provide students with a description of the most numerically prominent faith traditions in the United States. Since clients are most likely to come from these traditions, it is critical that social workers have some comprehension of the nation's largest faith groups and their animating value systems. Since, to some extent, most of the research and theory is based upon these populations, it helps to have some level of understanding of the nation's spiritual demographics in order to integrate the former content areas.

Gallup and Castelli's (1989) text, especially chapter 4, provides a comprehensive overview of the major denominations and faith-based groups in the country, including Evangelicals, Catholics, Mormons, Jews, and "nones." Also examined are the distinctive profiles of African Americans, Hispanics, teenagers, and Baby Boomers. While the material is somewhat dated, religious demographics remain relatively stable over time (Gallup \& Castelli, 1989) as more recent data confirm (Hutchison, 1999).

For further reflection, individuals may wish to delineate the major faith groups in the nation, then map out the number of close friends in each group, paying attention to their level of orthodoxy or commitment to the historic mainstream tenets of their faith tradition. Of particular note is the degree of homogeneity vs. the degree of diversity. If one's social network is largely comprised of, for example, members of liberal denominations, nominal adherents, and "nones," it is important to reflect upon how this may affect interaction with groups, such as Evangelicals, who tend to have a different value system. Similarly, if one's social network primarily consists of devout Mormons, reflection upon the possible difficulties involved with working with more liberal groups is called for. 


\section{OVERVEWOF MAJOR SPIRITUAL TRADITIONS}

As an extension of the above material, this content area provides more specific information about major spiritual traditions that social workers are likely to encounter. Articles in this domain can introduce readers to the unique beliefs, practices, values, and assets associated with the specific spiritual tradition under discussion. By providing students with a basic understanding of the value system that guides adherents, social workers are better equipped to provide services that are culturally competent as stipulated by the code of ethics (1.05).

The following is a core list of common spiritual traditions that cover the majority of clients with whom social workers are likely to encounter in practice settings (Gallup \& Castelli, 1989; Hutchison, 1999). Depending on such factors as time restraints and, perhaps, more importantly, the spiritual demographics of the area in which the course is taught, it may be appropriate to add material that addresses such traditions as Mormonism (Ulrich, Richards \& Bergin, 2000), Islam (Daneshpour, 1998), Judaism (Zedek, 1998), Pentecostalism (Dobbins, 2000), Hinduism (Juthani, 1998), Buddhism (Scotton, 1998), Native American spirituality (Trujillo, 2000), and/or other traditions. In short, the content in this domain should be tailored to equip course participants with understanding the faithbased cultures they are most likely to encounter in practice settings.

Evangelical Christians are the nation's largest spiritual minority (Hutchison, 1999). DiBlasio (1988) provides an introduction to this population and discusses some of the implications of an Evangelical worldview for therapy. Catholics comprise the second largest spiritual tradition and the nation's largest denomination. Shafranske (2000) provides an overview of this tradition, highlighting issues of importance to practitioners. McCullough, Weaver, Larson, and Aay (2000) provide a review of mainline Protestants, which includes an overview of their history, fundamental beliefs and practices, views on social and moral issues, and suggestions for practice. A brief introduction to Eastern faiths is offered by Ryan (1993), who reviews Hinduism, Buddhism, Confucianism, and Taoism in the context of death and dying work.

As mentioned above, this list should be adapted to reflect the client populations which course participants are likely to encounter in practice settings. It is critical, however, that the writings in this domain reflect an unbiased, empathetic tonethat communicates respect for the culture in question. Authors whose value systems are derived from the dominant secular culture, or whose value systems are otherwise incongruent with the group being discussed, can misrepresent faith-based cultures when value conflicts occur between the writer's value system and the population the author is addressing (Ginsberg, 1999; Wambach \& Van Soest, 1997). When writers encounter values that differ from their own, they may attempt to counter the group's beliefs or depict them as deficits, problems, or concerns instead of conveying a strengths-based depiction that genders an empathetic understanding.

For instance, one article on the Pentecostal experience seems to suggest that beliefs central to this faith group, such as believing that Jesus performed miracles or believing in the necessity of a spiritual re-birth, are either incorrect or problems (Belcher \& Cascio, 2001). While Enlightenment-based secular discourse commonly 
discounts the reality of the supernatural realm, applying this framework as an interpretive lens to minority faith groups facilitates misunderstanding in the same manner that applying a white lens facilitates misunderstanding of, for example, African-Americans. In short, the articles selected for this content area should reflect the same sensitivity to faith-based groups that is extended to other groups commonly discussed in social work forums.

To enhance learning, course participants might select one of the commonly encountered faith groups whose value system differs substantially from their own and attempt to envision life through that particular worldview. As part of this process, individuals might visit a house of worship and/ or obtain and read a variety of literature from a spiritual tradition that differs from their own, noting their personal reactions to these experiences.

The aim is to move toward spiritual competency by 1) developing an empathic understanding of a spiritually different worldview and 2) developing an awareness of one's personal spiritual worldview and associated biases (Sue, Arredondo \& McDavis, 1992). More specifically, using Evangelical Christians as a possible client population whose worldview differs from the students' own, one might reflect upon the lens or worldview through which Evangelicals are viewed, attempt to discern how the biases associated with their worldview affects their understanding of Evangelicals, consider how to set aside their worldview and associated biases and see reality through the worldview used by Evangelicals, and finally, come to the point of appreciating reality as seen through an Evangelical worldview (Wambach \& Van Soest, 1997).

\section{VALUE CONFLICTS}

Content on spiritual diversity flows naturally into a discussion on value conflicts that arise between subordinate and dominant spiritual worldviews. As implied above, conflict often occurs between the value system advocated by the dominant secular culture and the value systems of spiritual believers. As the CSWE educational standards (CSWE, 2001: IV, C) suggests, it is important for curriculum content to address issues of social justice and oppression. In order to work effectively with people of faith, it necessary to understand the bias they encounter in the dominant secular culture.

One of the more influential models for understanding value conflicts is Hunter's (1991) epistemological theory. This model posits that contemporary society is characterized by impulses towards two worldviews referred to by Hunter as orthodox and progressive. Orthodox believers derive their value system from transcendent authority, such as the Bible, the Koran, or the Dharma, while progressives individually construct their own value systems within the parameters proscribed by the current Enlightenment derived, secular ethos.

Two sections from Hunter's 1991 text provide a succinct introduction to this framework, the prologue "Stories from the front" (pp. 3-29) and "New lines of conflict: The argument in brief" (pp. 42-51). As implied above, the secular Enlightenment-based worldview referred to by Hunter as progressive dominates the centers of social power, particularly the reality defining the knowledge sector (e.g., media, academia, government bureaucracy, hel ping professions, etc.). 
As mentioned above, it is important to develop an empathetic understanding of the bias that the difference in worldviews between people of faith and progressives often engenders toward orthodox believers (Roberts, 1999). It may be helpful to recognize that the dominant progressive worldview often marginalizes or otherwise de-legitimizes devout faith in such influential knowledge sector forms as television (Skill \& Robinson, 1994; Skill, Robinson, Lyons \& Larson, 1994), popular periodicals (Perkins, 1984), high school (Sewall, 1995; Vitz, 1986; 1998) and college level textbooks (Glenn, 1997; Lehr \& Spilka, 1989), including social work texts (Cnaan, 1999; Hodge, Baughman \& Cummings, 2002). Stockton (1994) illustrates how the clash in value systems can lead to Muslims being depicted in an unfavorable light in media, a forum that shapes general perceptions about populations (Hunter \& Schaecher, 1995; Tower, 2000).

As one of the professions that comprise the knowledge sector, Hunter (1991) observes that a progressive worldview also pervades social work. One illustration of the salience of the progressive worldview in the profession is provided by the fact that some $60 \%$ to $70 \%$ of social workers reject the notion of a personal God in favor of non-theistic understandings of transcendent reality (Sheridan, Bullis, Adcock, Berlin \& Miller, 1992; Sheridan, Wilmer \& Atcheson, 1994). In contrast, at least $66 \%$ of the general population believe in a personal God (Canda \& Furman, 1999; Gallup \& Castelli, 1989). Furman, Perry, and Goldale's (1996) study demonstrates the effects that the difference in value systems can have on the willingness of some theistic clients to receive services from social workers who hold substantially different worldviews in tandem with little knowledge of spiritual diversity.

To enhance understanding in this area, course participants might consider which worldview they orient towards (i.e., orthodox or progressive) and how that particular orientation might affect their ability to work with clients from the alternative worldview in a culturally competent manner. A feminist, for example, might consider how her affirmation of the egalitarian gender roles might effect her ability to provider services to a Hindu couple that affirms complementary gender roles. Or to cite another example, an Evangelical Christian might reflect upon how her worldview might effect her ability to provide services to a sexually active gay man wrestling with the intersection between his spirituality and sexual behavior.

Material from the NASW Code of Ethics (NASW, 1999) might also be incorporated into assignments. Given that the Code of Ethics indicates that social workers should actively work to prevent and eliminate religious discrimination (standard $6.04 d$ ), individuals might deliberate upon the experiences of spiritual believers who encounter life in a culture that often ignores, devalues, and even ridicules their most cherished beliefs and values. Individuals might consider what actions they might take, both personally and systemically, on behalf of Evangelical Christians, traditional Catholics, Muslims, and people of faith from other traditions who often encounter bias in the dominant secular culture.

\section{SPIRITUALLY-BASED INTERVENTIONS}

Spiritually competent practice is predicated upon acquiring the ability to develop intervention strategies that are appropriate, relevant, and sensitive to the client's spiritual worldview (Sue et al., 1992). As the CSWE educational standards (Council 
on Social Work Education, 2001: IV, F) imply, practice should focus on the clients' spiritual strengths, capabilities, and resources.

Although it is important to consider interventions within the context of the specific spiritual tradition of the client, there are some interventions that have been empirically validated with a number of traditions. Perhaps the most widely used spiritual intervention is prayer. McCullough and Larson (1999) provide a helpful overview of prayer, including information about its frequency, various manifestations, associations with well-being, and its function as a resource for practitioners.

Incorporating spiritual beliefs into traditional cognitive/ behavioral modalities is also a widely used intervention. Studies suggest that a spiritually modified form of cognitive/ behavioral therapy is at least as effective as traditional forms of therapy in a number of areas, including depression among Christians (Hawkins, Tan \& Turk, 1999; Johnson, Devries, Ridley, Pettorini \& Peterson, 1994; Johnson \& Ridley, 1992; Propst, 1996), perfectionism among Mormons (Richards, Owen \& Stein, 1993), and anxiety disorders (Azhar, Varma \& Dharap, 1994), bereavement (Azhar \& Varma, 1995a), and depression (Azhar \& Varma, 1995b) among Muslims. Propst (1996) provides a good introduction to this approach.

A significant body of research also testifies to the importance of spirituality as a mechanism for coping (Pargament, 1997). Pargament, individually (Pargament, 1996) and in association with Brant (Pargament \& Brant, 1998), overviews some of the more salient features of spiritual coping. Options for reframing difficulties as opportunities for spiritual growth are presented along with spiritual beliefs that may facilitate healthy spiritual coping.

Spiritual resources can also be tapped into to facilitate forgiveness, which is a major component of most major faith traditions (McCullough, Paragament \& Thoresen, 2000). DiBlasio (1998) gives a helpful account of the use of decisionbased forgiveness in therapeutic contexts.

To promote further assimilation of the above material, individuals might consider selecting one or more interventions and one or more of the spiritual traditions listed above. Course participants could reflect upon how the intervention(s) could be tailored to assist a client from a particular tradition. In other words, how might the intervention be customized to achieve therapeutic goals by tapping into a client's spiritual value system? To use Muslims as an example, students might consider the tenets that might be drawn from the Koran and those integrated into traditional cognitive interventions to assist a client who is wrestling with depression.

\section{ASSESSING AND OPERATIONALIZING SPIRITUAL STRENGTHS}

A number of frameworks have been developed to assess and operationalize clients' spiritual strengths. One of the more common approaches is taking a spiritual history (Boyd, 1998; Bullis, 1996; Canda \& Furman, 1999; Dombeck \& Karl, 1987; O'Rourke, 1997; Peck, 1993; Rizzuto, 1996; Tan, 1996). This process is analogous to taking a family history except the format is tailored to elicit the significant spiritual events that have occurred over the course of a client's life. For further specificity, Boyd's (1998) model might be presented. 
While spiritual histories offer a verbal format for spiritual assessment, Hodge's (2002) spiritual life map provides a pictorial delineation of a client's spiritual journey. In their most basic form, clients use drawing pencils to map out their spiritual life history on a large piece of paper. Significant events, in the form of pictures, words, symbols, or other entities that resonate with the client's experiences are depicted on a path, a roadway, or a single line that represents the client's spiritual sojourn, typically from birth to the afterlife.

Spiritual genograms offer another method for accessing the spiritual dimension of existence (Bullis, 1990; Dunn \& Dawes, 1999; Frame, 2000; Hodge, 2001; Rey, 1997; Roberts, 1999). As is the case with traditional genograms, spiritual genograms focus on the intergenerational aspects of spirituality. Hodge (2001) provides a good example of this assessment method while highlighting interventions that may be particularly suited to this approach.

While spiritual genograms highlight spiritual strengths over time, spiritual ecomaps emphasize spiritual strengths in space (Hodge, 2000). Put differently, while spiritual genograms focus on intergenerational strengths, spiritual ecomaps accent strengths that exist in the current environment. Hodge (2000) provides an introduction to this diagrammatic instrument.

These assessment approaches provide social workers with a set of tools that emphasize different aspects of clients' spirituality and, correspondingly, lend themselves to the operationalization of different spiritual strengths. Assessments conducted with spiritual genograms, for instance, may reveal spiritual assets in a client's family system that other methods might fail to uncover.

To promote a better understanding of these assessment approaches, course participants might list the strengths and limitations of each method. Areas to consider include ease of client involvement, client preference, ability to tap particular strengths, and smoothness of transition to particular interventions. For example, spiritual genograms may be particularly appropriate with clients where the extended family plays a significant role in clients' lives, while spiritual eco-maps may be better suited to clients who wish to focus on their immediate presenting problem. Similarly, spiritual histories may be ideal for verbally oriented clients, while more artistic or less verbal clients may find lifemaps a better choice.

\section{RIGHTSOF SPIRITUAL BELIEVERS}

When addressing spirituality, issues related to the free expression of religion arise with some degree of frequency. To use Hunter's (1991) terminology, orthodox believers may encounter discrimination in forums in which progressives dominate. For instance, school social workers may have to address situations in which students are sanctioned for wearing spiritually-based attire or sharing their spiritual beliefs in class settings. Consequently, it is important for social workers to have some knowledge of the rights that spiritual believers possess in public forums.

The updated version of former President Clinton's (1995) memorandum on religious expression in the public schools provides a helpful summary of the free expression rights of believers (Riley, 1998). Also helpful is Esbeck's (1998) review of Supreme Court decisions bearing on First Amendment freedoms. In addition to 
the First Amendment of the United States Constitution, the United Nations (1948/1998) Universal Declaration of Human Rights is also an original source that contains material that directly relates to individuals' religious rights.

To promote further understanding of this material, students might summarize the rights that spiritual believers have. Alternatively, course participants could take a scenario of relevance to social work, such as a student in school or an employee at work, and list the rights that people of faith enjoy in these settings. Students might explore how a social worker might advocate for a client who has been denied religious rights or is facing sometype of religious discrimination. For example, individuals might examine the steps that a school social worker might take on behalf of a devout Muslim student whose paper on Islam is rejected out-of-hand solely due to its spiritual content.

In addition, in keeping with the CSWE educational standards (CSWE, 2001: IV, E), students might analyze social welfare policy and services in light of the religious rights believers possess. For instance, individuals might explore ways in which public policy conflicts with the rights of spiritual believers. The Unlevel Playing Field (White House, 2001), an examination of faith-based barriers that exist in federal social service programs, might be used as a starting point.

\section{ASSIGNMENT SUGGESTIONS}

In addition to the domain-related mini-assignments discussed above, a number of major assignments can also be incorporated into the curriculum. These projects provide opportunities for course participants to develop a deeper, more personal understanding of many of the themes presented above in a manner that is congruent with CSWE educational standards (Council on Social Work Education, 2001: IV). Although any number of assignments could be proposed, the three discussed below may be particularly helpful.

\section{Spiritual Autobiography}

Spiritual autobiographies can be helpful tools for fostering student awareness of their own unique spiritual history. Writing a spiritual autobiography can assist individuals to understand their spiritual values and how these values have informed their lives. Individuals can chronicle their own relationship with the transcendent, including parental influences, spiritual awakenings, key turning points, specific spiritual strengths, how their spirituality has helped them to cope with trials, and how their spirituality has functioned as a protective factor in their lives.

Since this exercise is designed to foster increased self-awareness regarding one's personal spiritual journey, it may be particularly advisable to undertake this project early in the course. Spirituality can be defined in a broad manner so that all individuals can discuss how their views regarding transcendent reality have informed their lives (Canda \& Furman, 1999). For individuals interested in a model, the Confessions by African spirituality writer Augustine (354-430/1991), widely considered to be the first autobiographical work in recorded human history (Clark, 1993), can be used. 


\section{Religious Countertransference}

As course participants develop awareness of their own spiritual values, it is important to consider how those values may interact with the spiritual values of clients. In some situations, value systems may interact in a manner that inhibits the provision of client-centered services. The effectiveness of service provision may be particularly imperiled when individuals hold negative sentiment toward other spiritual traditions (Genia, 2000; Larson, Sherrill \& Lyons, 1994).

Approximately one-third of social workers report ambivalent-to-negative feelings towards their religious background, which is primarily Christianity (Canda \& Furman, 1999; Furman, Canda \& Benson, 2001; Sheridan et al., 1992). For instance, $44 \%$ of Virginia-based clinical practitioners $(\mathrm{N}=108)$ no longer participate in their childhood religious tradition, with the shift occurring primarily away from Christianity to none or "other" (Sheridan et al., 1992).

As Genia (2000) observes, individuals who havefailed to work through these negative feelings may encounter religious countertransference biases when working with individuals from their former spiritual traditions. Internal pressures from unresolved personal needs can drive interactions with devout clients from the Christian faith tradition and perhaps other traditions that affirm similar values (Black, Jeffreys \& Hartley, 1993). Interactions with committed Christians may result in social workers acting out their unresolved negative feelings toward their past traditions with their present clients (Gartner, Harmatz, Hohmann, Larson \& Gartner, 1990).

Accordingly, course participants might write a paper exploring their ability to work with clients from other spiritual traditions. Particular attention should focus on examining negative sentiments towards one's former childhood spiritual tradition and how unresolved issues might affect service provision. Thought could also go into deciding what emotional signals might indicate the necessity of a referral to another practitioner.

This paper might be written later in the course, perhaps as a useful complement to the "values conflicts" content area. Since this domain directly addresses the issue of conflicting worldviews, course participants are already thinking about macro level, epistemologically-based conflicts. As a supplemental assignment, this paper can assist individuals explore micro-level conflicts that may affect their ability to work with clients from differing spiritual traditions.

\section{Spiritual Assessment Reflection Papers}

Course participants might also benefit from writing a number of reflection papers on the spiritual assessment process. In conjunction with the "Assessing and Operationalizing Spiritual Strengths" topic area, course participants might form dyads and taketurns conducting spiritual assessments. Oneindividual could present with a particular problem, while the other conducts an assessment with the aim of eliciting spiritual strengths that might be operationalized to help ameliorate the presenting problem. After completion, the roles could be reversed.

Depending on time constraints, this process could be undertaken for each of the four assessment approaches profiled above. In other words, each course partici- 
pant would play the part of a practitioner conducting four assessments, using a spiritual history, a spiritual lifemap, a spiritual genogram, and a spiritual ecomap. Concurrently, each individual would also serve as a client, experiencing each assessment approach from the vantage point of a social service consumer.

After completing an assessment, each person in the dyad might write a paper reflecting on his or her experiences. Attention should be directed towards regarding the extent to which spiritual strengths were identified and harnessed to address the presenting problem and how both members of the dyad experienced the process. Particular attention should focus on practices that promote or hinder a spirit of openness and acceptance in the clinical dialogue and alternative practices that might better achieve these goals.

After completing the reflection papers, the dyad members might exchange papers and discuss ways in which the individual who role-played the clinician might improve his or her ability to conduct a spiritual assessment. Points of congruence, in which both participants shared similar perceptions, should be noted as well as areas in which perceptions differed. The individual who functioned as the client should note the strengths of the person conducting the assessment and offer suggestions for building upon those strengths to improve his or her ability as a clinician. Finally, as is the case with all group exercises, issues of student privacy, comfort level, and group dynamics should be considered before engaging in the above exercise.

\section{CONCLUSIONS}

Most social workers seem interested in learning more about spirituality (Derezotes, 1995). Given that the majority of social workers appear to address spirituality in practice settings without proper training (Canda \& Furman, 1999; Furman et al., unpublished manuscript), it is critical that resources be developed that can be used to equip practitioners to work with spirituality in an ethically consistent manner. While individuals interested in engaging spiritual issues on a regular basis should be encouraged to develop an extensive knowledge base concerning the major spiritual traditions they are likely to encounter in practice settings, the curriculum content presented in this paper provides a basic foundation on which to build. In short, the material presented in this paper lays the groundwork for spiritually competent practice.

\section{References}

Augustine. (1991). Confessions (H. Chadwick, Trans.). pp. 354-430. New York: Oxford University Press.

Azhar, M.Z., \& Varma, S.L. (1995a). Religious psychotherapy as management of bereavement. Acta Psychiatrica Scandinavica, 91(4), 233-235.

Azhar, M.Z., \& Varma, S.L. (1995b). Religious psychotherapy in depressive patients. Psychotherapy and Psychosomatics, 63 (3-4), 165-173.

Azhar, M.Z., Varma, S.L., \& Dharap, A.S. (1994). Religious psychotherapy in anxiety disorder patients. Acta Psychiatrica Scandinavica, 90, 1-2.

Bart, M. (1998). Spirituality in counseling finding believers. Counseling Today, 41(6), 1,6. 
Belcher, J.R., \& Cascio, T. (2001). Social work and deliverance practice: The pentecostal experience. Families in Society, 82(1), 61-68.

Black, P.N., Jeffreys, D., \& Hartley, E.K. (1993). Personal history of pscyhosocial trauma in the early life of social work and business students. Journal of Social Work Education, 29(2), 171-180.

Boyd, T.A. (1998). Spiritually sensitive assessment tools for social work practice. In B. Hugen (Ed.), Christianity and social work: Readings on theintegration of Christian faith and social work practice ( $p p$. 239-255). Botsford, CT: NACSW Press.

Bullis, R.K. (1990). Spiritual genograms: Nurturing our spiritual roots. Church Teachers, 17(5), 174-175, 190-191.

Bullis, R.K. (1996). Spirituality in social work practice Washington, DC: Taylor \& Francis.

Calhoun-Brown, A. (1998). While marching to Zion: Other worldliness and racial empowerment in the black community. Journal for the Scientific Study of Religion, 37(3), 427-439.

Canda, E.R., \& Furman, L.D. (1999). Spiritual diversity in social work practice New York: The Free Press.

Clark, G. (1993). Augustine, the confessions. New York: Cambridge University Press.

Clinton, W.J. (1995). Memorandum for the U.S. Secretary of Education and the U.S. Attorney General. Retrieved December 11, 1999, from: http:// w3.trib.com/FACT/ 1st.pres.rel.html.

Cnaan, R.A. (1999). Thenewer deal. New York: Columbia University Press.

Council on Social Work Education. (2001). Educational policy and accreditation standards. Retrieved December 12, 2001, from: http://cswe.org/accreditation/EPAS/EPAS start.htm.

Daneshpour, M. (1998). Muslim families and family therapy. Journal of Marital and Family Therapy, 24(3), 355-390.

Derezotes, D.S. (1995). Spirituality and religiosity: Neglected factors in social work practice. Arete, 20(1), 1-15.

DiBlasio, F.A. (1988). Integrative strategies for family therapy with Evangelical Christians. Journal of Psychology and Theology, 16(2), 127-134.

DiBlasio, F.A. (1998). The use of a decision-based forgiveness intervention within intergenerational family therapy. Journal of Family Therapy, 20(1), 77-94.

Dobbins, R.D. (2000). Psychotherapy with Pentecostal Protestants. In P.S. Richards \& A.E. Bergin (Eds.), Handbook of psychotherapy and religious diversity (pp. 155-184). Washington, DC: American Psychological Association.

Dombeck, M., \& Karl, J. (1987). Spiritual issues in mental health care. Journal of Religion and Health, 26(3), 183-197.

Donahue, M., \& Benson, P.L. (1995). Religion and the well-being of adolescents. Journal of Social Issues, 51(2), 145-160.

Dunn, A.B., \& Dawes, S.J. (1999). Spirituality-focused genograms: Keys to uncovering spiritual resources in African American families. Journal of Multicultural Counseling and Development, 27(1), 240-254.

Ellison, C.G., \& Levin, J.S. (1998). The religion-health connection: Evidence, theory, and future directions. Health Education and Behavior, 25(6), 700-720.

Esbeck, C.H. (1998). Equal treatment: Its constitutional status. In S.V. Monsma \& J.C. Soper (Eds.), Equal treatment of religion in a pluralistic society (pp. 9-29). Grand Rapids: Eerdmans Publishing.

Ferraro, K.F., \& Kelley-Moore, J.A. (2000). Religious consolation among men and women: Do health problems spur seeking? Journal of theScientific Study of Religion, 39(2), 220-234.

Frame, M.W. (2000). The spiritual genogram in family practice. Journal of Marital and Family Therapy, 26(2), 211-216.

Furman, L.D., Benson, P.W., Grimwood, C., \& Franz, J. (2002). Religion and spirituality at the millennium: Descriptivefindings from a survey of UK social workers.

Furman, L.D., Canda, E.R., \& Benson, P.W. (2001). Implications of religion and spirituality in social work practice: Descriptivefindings from U.S. survey. Unpublished manuscript.

Furman, L.D., \& Chandy, J.M. (1994). Religion and spirituality: A long-neglected cultural component of rural social work practice. Human Services in the Rural Environment, 17(3/4), 21-26. 
Furman, L.D., Perry, D., \& Goldale, T. (1996). Interaction of Evangelical Christians and social workers in the rural environment. Human Services in the Rural Environment, 19(3), 5-8.

Gallup, G.J., \& Castelli, J. (1989). The people's religion: American faith in the 90s. New York: Macmillan Publishing.

Gallup, G.J., \& Lindsay, D.M. (1999). Surveying the religious landscape Harrisburg, PA: Morehouse Publishing.

Gartner, J.D. (1996). Religious commitment, mental health, and prosocial behavior: A review of the empirical literature. In E.P. Shafranske (Ed.), Religion and the clinical practice of psychology (pp. 187-214). Washington, DC: American Psychological Association.

Gartner, J., Harmatz, M., Hohmann, A., Larson, D., \& Gartner, A.F. (1990). The effects of patient and clinician ideology on clinical judgment: A study of ideological countertransference. Psychotherapy, 27(1), 98106.

Genia, V. (2000). Religious issues in secularly based psychotherapy. Counseling and Values, 44(3), 213-221.

Ginsberg, L. (1999). Reviewers, orthodoxy, and the passion to publish. Research on Social Work Practice, 9(1), 100-103.

Glenn, N. (1997). Closed hearts, closed minds: The textbook story of marriage New York: Institute for American Values.

Green, L.L., Fullilove, M.T., \& Fullilove, R. (1998). Stories of spiritual awakening: The nature of spiritual recovery. Journal of Substance Abuse Treatment, 15(4), 325-331.

Halstead, J.M., \& Lewicka, K. (1998). Should homosexuality betaught as an acceptablealternative lifestyle? A Muslim perspective. Cambridge Journal of Education, 28(1), 49-64.

Hawkins, R.S., Tan, S.-Y., \& Turk, A.A. (1999). Secular versus Christian inpatient cognitive-behavioral therapy programs: Impact on depression and spiritual well-being. Journal of Psychology and Theology, 274(4), 309-318.

Hodge, D.R. (2000). Spiritual ecomaps: A new diagrammatic tool for assessing marital and family spirituality. Journal of Marital and Family Therapy, 26(1), 229-240.

Hodge, D.R. (2001). Spiritual genograms: A generational approach to assessing spirituality. Families in Society, 82(1), 35-48.

Hodge, D.R. (2002). Spiritual lifemaps: A client-centered pictorial instrument for spiritual assessment, planning, and intervention. Social Work.

Hodge, D.R., Baughman, L.M., \& Cummings, J.A. (2002, February 24-27). Moving toward spiritual competency: Deconstructing religious stereotypes and spiritual prejudices in social work literature. Paper presented at the [Forty-eighth annual program meeting] Council on Social Work Education. Nashville, TN.

Hunter, J.D. (1991). Culturewars. New York: Basic Books.

Hunter, J., \& Schaecher, R. (1995). Gay and lesbian adolescents. In R.L. Edwards (Ed.), Encydopedia of Social Work (19, Vol. 2, pp. 1055-1063). Washington, DC: NASW Press.

Hutchison, E.D. (1999). Dimensions of human behavior. Thousand Oaks, CA: Pine Forge Press.

Islamic Society of North America. (1999). Homosexuality. In issues and questions. Retrieved October 21, 1999 from: http:// www.isna.net/iq.htm.

Jacobs, J.L. (1992). Religious ritual and mental health. In J. Schumaker (Ed.), Religion and mental health (pp. 291-299). New York: Oxford University Press.

Jafari, M.F. (1993). Counseling values and objectives: A comparison of western and Islamic perspectives. TheAmerican Journal of Islamic Social Sciences, 10(3), 326-339.

Johnson, W.B., Devries, R., Ridley, C.R., Pettorini, D., \& Peterson, D.R. (1994). The comparative efficacy of Christian and secular rational-emotive therapy with Christian clients. Journal of Psychology and Theology, 22(2), 130-140.

Johnson, W.B., \& Ridley, C.R. (1992). Brief Christian and non-Christian rational-emotive therapy with depressed Christian clients: An exploratory study. Counseling and Values, 36(6), 220-229.

Juthani, N.V. (1998). Understanding and treading Hindu patients. In H.G. Koenig (Ed.), Handbook of religion and mental health (pp. 271-278). New York: Academic Press. 
Kennedy, J.E., Davis, R.C., \& Talyor, B.G. (1998). Changes in spirituality and well-being among victims of sexual assault. Journal for theScientific Study of Religion, 37(2), 322-328.

Kirkpatrick, L.A. (1995). Attachment theory and religious experience. In R.W. Hood (Ed.), Handbook of religious experience (pp. 446-475). Birmingham, AL: REP Publishers.

Koenig, H.G., McCullough, M.E., \& Larson, D.B. (2001). Handbook of religion and health. New York: Oxford University Press.

Larson, D.B., Sherrill, K.A., \& Lyons, J.S. (1994). Neglect and misuse of the R word. In J.S. Levin (Ed.), Religion in aging and health (pp. 178-195). London: Sage.

Lehr, E., \& Spilka, B. (1989). Religion in the introductory psychology textbook: A comparison of three decades. Journal for the Scientific Study of Religion, 28(3), 366-371.

Lindsey, E.W., Kurtz, P.D., Jarvis, S., Williams, N.R., \& Nackerud, L. (2000). How runaway and homeless youth navigate troubled waters: Personal strengths and resources. Child and Adolescent Social Work Journal, 17(2), 115-140.

Maslow, A.H. (1968). Toward a psychology of being. Princeton: D. Van Nostrand.

Maton, K.I., \& Salem, D.A. (1995). Organizational characteristics of empowering community settings: A multiple case study approach. American Journal of Community Practice, 23(5), 631-656.

Maton, K.I., \&Wells, E.A. (1995). Religion as a community resource for well-being: Prevention, healing, and empowerment pathways. Journal of Social Issues, 51(2), 177-193.

McCullough, M.E., \& Larson, D.B. (1999). Prayer. In W.R. Miller (Ed.), Integrating spirituality into treatment (pp. 85-110). Washington, DC: American Psychological Association.

McCullough, M.E., Paragament, K.I., \&Thoresen, C.E. (Eds.). (2000). Forgiveness. New York: Guilford Press.

McCullough, M.E., Weaver, A.J., Larson, D.B., \& Aay, K.R. (2000). Psychotherapy with mainline Protestants: Lutheran, Presbyterian, Episcopal/Anglican, and Methodist. In P.S. Richards \& A.E. Bergin (Eds.), Handbook of psychotherapy and religious diversity (pp. 105-129). Washington, DC: American Psychological Association.

McFadden, S.H., \& Levin, J.S. (1996). Religion, emotions and health. In C. Magai \& S.H. McFadden (Eds.), Handbook of emotion, adult development, and aging (pp. 349-365). San Diego: Academic Press.

McRae, M.B., Thompson, D.A., \& Cooper, S. (1999). Black churches as therapeutic groups. Journal of Multicultural Counseling and Development, 27(1), 207-220.

Montgomery, C. (1994). Swimming upstream: The strengths of women who survive homelessness. Advances in Nursing Science, 16(3), 34-45.

National Association of Social Workers. (1999). Code of Ethics. Retrieved January 1, 2000 from: www.naswdc.org/Code/ ethics.htm.

Nathanson, I.G. (1995). Divorce and women's spirituality. Journal of Divorceand Remarriage, 22(3/4), 179188.

O'Rourke, C. (1997). Listening for the sacred: Addressing spiritual issues in the group treatment of adults with mental illness. Smith College of Studies in Social Work, 67(2), 179-196.

Pargament, K.I. (1996). Religious methods of coping: Resources for the conversation and transformation of significance. In E.P. Shafranske (Ed.), Religion and the clinical practice of psychology (pp. 213-239). Washington, DC: American Psychological Association.

Pargament, K.I. (1997). The psychology of religion and coping. New York: Guilford Press.

Pargament, K.I. (1999). The psychology of religion and spirituality?Yes and no. The International Journal for the Psychology of Religion, 9(1), 3-16.

Pargament, K.I., \& Brant, C.R. (1998). Religion and coping. In H.G. Koenig (Ed.), Handbook of religion and mental health (pp. 111-128). New York: Academic Press.

Patterson, J., Hayworth, M., Turner Christie, \& Raskin, M. (2000). Spiritual issues in family therapy: A graduate-level course. Journal of Martial and Family Therapy, 26(2), 199-210.

Peck, M.S. (1993). Further along theroad less traveled. New York: Simon \& Schuster.

Perkins, H.W. (1984). Religious content in American, British, and Canadian popular publications from 1937 to 1979. Sociological Analysis, 45(2), 159-165. 
Privette, G., Quackenbos, S., \& Bundrick, C.M. (1994). Preferences for religious and nonreligious counseling and psychotherapy. Psychological Reports, 75(1, Pt 2), 539-546.

Propst, L.R. (1996). Cognitive-behavioral therapy and the religious person. In E.P. Shafranske (Ed.), Religion and the dinical practice of psychology (pp. 391-407). Washington, DC: American Psychological Association.

Rey, L.D. (1997). Religion as invisible culture: Knowing about and knowing with. Journal of Family Social Work, 2(2), 159-177.

Richards, P.S., Owen, L., \& Stein, S. (1993). A religiously oriented group counseling intervention for selfdefeating perfectionism: A pilot study. Counseling and Values, 37, 96-104.

Richards, P.S., Rector, J.M., \& Tjeltveit, A.C. (1999). Values, spirituality, and psychotherapy. In W.R. Miller (Ed.), Integrating spirituality into treatment (pp. 133-160). Washington, DC: American Psychological Association.

Riley, R.W. (1998). Religious expression in public schools. Retrieved July 11, 2001 from: http:// www.ed.gov/Speeches/08-1995/religion.html.

Rizzuto, A.-M. (1996). Psychoanalytic treatment and the religious person. In E. Shafranske (Ed.), Religion and the clinical practice of psychology (pp. 409-431). Washington, DC: American Psychological Association.

Roberts, J. (1999). Heart and Soul. In F. Walsh (Ed.), Spiritual resourcesin family therapy (pp. 256-271). New York: Guilford Press.

Robinson, F. (1996). African American women leaders in the community college: Where they get their strengths. Thresholds in Education, 22(1), 49-52.

Ryan, D. (1993). Death: Eastern perspectives. In K.J. Doka \&J.D. Morgan (Eds.), Death and spirituality (pp. 75-92). Amityville, NY: Baywood.

Scheepers, P., \&Van Der Slik, F. (1998). Religion and attitudes on moral issues: Effects of individual, spouse and parental characteristics. Journal for the Scientific Study of Religion, 37(4), 678-691.

Scotton, B.W. (1998). Treating Buddhist patients. In H.G. Koenig (Ed.), Handbook of religion and mental health (pp. 263-270). New York: Academic Press.

Sewall, G.T. (1995). Religion in the classroom: What the textbooks tell us. New York: American Textbook Council.

Shafranske, E.P. (2000). Psychotherapy with Roman Catholics. In P.S. Richards \& A.E. Bergin (Eds.), Handbook of psychotherapyand religious diversity (pp. 59-88). Washington, DC: American Psychological Association.

Sheridan, M.J., \& Amato-von Hemert, K. (1999). The role of religion and spirituality in social work education and practice: A survey of student views and experiences. Journal of Social Work Education, 35(1), 125-141.

Sheridan, M.J., Bullis, R.K., Adcock, C.R., Berlin, S.D., \& Miller, P.C. (1992). Practitioners' personal and professional attitudes and behaviors toward religion and spirituality: Issues for education and practice. Journal of Social Work Education, 28(2), 190-203.

Sheridan, M.J., Wilmer, C.M., \& Atcheson, L. (1994). Inclusion of content on religion and spirituality in the social work curriculum: A study of faculty views. Journal of Social Work Education, 30(3), 363-376.

Skill, T., \& Robinson, J.D. (1994). The image of Christian leaders in fictional television programs. Sociology of Religion, 55(1), 75-84.

Skill, T., Robinson, J.D., Lyons, J.S., \& Larson, D. (1994). The portrayal of religion and spirituality on fictional network television. Review of the Religious Research, 35(3), 251-267.

Stockton, R. (1994). Ethnic archetypes and the Arab image. In E. McCarus (Ed.), The development of ArabAmerican identity (pp. 119-153). Ann Arbor: The University of Michigan Press.

Sue, D.W., Arredondo, P., \& McDavis, R.J. (1992). Multicultural counseling competencies and standards: A call to the profession. Journal of Counseling and Development, 70(4), 477-486.

Sullivan, W.P. (1997). On strengths, niches, and recovery from serious mental illness. In D. Saleebey (Ed.), Thestrengths perspective in social work practice (pp. 183-199). White Plains, NY: Longman. 
Talbot, M. (2000, February 27). A mighty fortress. The New York Times Magazine, 34-41, 66-68, 84-85.

Tan, S.-Y. (1996). Religion in clinical practice: Implicit and explicit integration. In E. Shafranske (Ed.), Religion and the dinical practice of psychology (pp. 365-387). Washington, DC: American Psychological Association.

Tower, K. (2000). In our own image: Shaping attitudes about social work through television production. Journal of Social Work Education, 36(3), 575-585.

Trujillo, A. (2000). Psychotherapy with Native Americans: A view into the role of religion and spirituality. In R.P. Scott \& A.E. Bergin (Eds.), Handbook of psychotherapy and religious diversity (pp. 445-466). Washington, DC: American Psychological Association.

Turner, N.H., O’Dell, K.J., \&Weaver, G.D. (1999). Religion and the recovery of addicted women. Journal of Religion and Health, 38(2), 137-148.

Ulrich, W.L., Richards, P.S., \& Bergin, A.E. (2000). Psychotherapy with Latter-Day Saints. In P.S. Richards \& A.E. Bergin (Eds.), Handbook of psychotherapy and religious diversity (pp. 185-209). Washington, DC: American Psychological Association.

United Nations. (1948/1998). Universal Declaration of Human Rights. Retrieved April 4, 1999 from: http://www.org/Overview/rights.html.

Vitz, P.C. (1986). Censorship: Evidence of biasin our children's textbooks. Ann Arbor, MI: Servant Books.

Vitz, P.C. (1998). Thecourseof truelove: Marriagein high school textbooks. New York: Institutefor American Values.

Wambach, K.G., \&Van Soest, D. (1997). Oppression. In R.L. Edwards (Ed.), Encyclopedia of Social Work (19"h ed., pp. 243-252). Washington, DC: NASW Press.

Weaver, A.J., Koenig, H.G., \& Larson, D.B. (1997). Marriage and family therapists and the clergy: A need for clinical collaboration, training, and research. Journal of Marital and Family Therapy, 23(1), 13-25.

The White House. (2001, August). Unlevel playing field: Barriers to participation by faith-based and community organizations in federal social service programs. Retrieved January 21, 2003 from: http://www.whitehouse.gov/ news/releases/2001/08/unlevelfield.html.

Worthington, E.J., Kurusu, T., McCullough, M., \& Sandage, S. (1996). Empirical research on religion and psychotherapeutic processes and outcomes: A 10-year review and research prospectus. Psychological Bulletin, 119(3), 448-487.

Zedek, M.R. (1998). Religion and mental health from the Jewish perspective. In H.G. Koenig (Ed.), Handbook of religion and mental health (pp. 255-261). New York: Academic Press.

\section{Author's Note:}

Address correspondence to: David R. Hodge, M.C.S., M.S.W., GeorgeWarren Brown School of Social Work, Washington University, 1 Brookings Drive, Campus Box 1196, St. Louis, MO 63130-4899, USA. E-mail: drh1@gwbmail.wustl.edu. 